\title{
Group size and composition of Guiana dolphins (Sotalia guianensis) (Van Bénèden, 1864) in the Paranaguá Estuarine Complex, Brazil
}

\author{
Santos, MCO. ${ }^{\text {* }}$, Oshima, JEF. ${ }^{\mathrm{a}}$ Pacífico, ES. ${ }^{\mathrm{a}}$ and Silva, E. ${ }^{\mathrm{a}}$ \\ aProjeto Atlantis, Laboratório de Biologia da Conservação de Cetáceos, \\ Departamento de Zoologia, Instituto de Biociências, Campus Rio Claro, \\ Universidade Estadual Paulista, "Júlio de Mesquita Filho" - UNESP, \\ Av. 24-A, 1.515, CEP 13506-900 Bela Vista, Rio Claro, SP, Brazil \\ *e-mail: sotalia@gmail.com
}

Received May 7, 2008 - Accepted February 17, 2009 - Distributed February 28, 2010

(With 3 figures)

\begin{abstract}
The aim of the present study was to describe the characteristics of Guiana dolphins (S. guianensis) group size and composition in the Paranaguá Estuarine Complex ( $25^{\circ} 15^{\prime}-25^{\circ} 36^{\prime} \mathrm{S}$ and $48^{\circ} 02^{\prime}-48^{\circ} 45^{\prime} \mathrm{W}$ ), Paraná State, as well as to verify the existence of relationships between a given environmental variable (water depth, salinity, transparency and temperature) and group size. An area of around $124 \mathrm{~km}^{2}$ was surveyed by boat from April 2006 to February 2008 in the following subsets of the estuary: Canal do Superagui $\left(\sim 28 \mathrm{~km}^{2}\right)$, Pinheiros bay $\left(\sim 34 \mathrm{~km}^{2}\right)$, part of Laranjeiras bay, which included the Guaraqueçaba sub-estuary $\left(\sim 38 \mathrm{~km}^{2}\right)$, and part of the Mixture Section of the Paranaguá Estuarine Complex $\left(\sim 24 \mathrm{~km}^{2}\right)$. In 45 survey days, a total of 147 hours were spent observing 286 groups of S. guianensis. Groups varied from two individuals to aggregations of up to 90 individuals (mean \pm SD: 11.5 \pm 14 .4 individuals). Solitary individuals were seen only on five occasions ( $1.7 \%$ of all observations). Groups with calves $(n=247)$ represented $86.4 \%$ overall and were more common in all sub-areas when compared to groups without calves. Groups without calves were found in all sub-areas and were usually smaller and composed of up to 12 individuals. A usual group composition of $70 \%$ of adults and $30 \%$ of calves was observed considering all sub-areas and seasons. No correlations were found between group size and water temperature (Spearman's rank test, $r=0.0059, p=0.9338$ ), transparency (Spearman's rank test, $r=0.0597, p=0.9333$ ), depth (Spearman's rank test, $r=0.1421, p=0.4698$ ), and salinity (Spearman's rank test, $r=-0.1938, p=0.0665$ ). While Guiana dolphin groups were seen in the entire surveyed area, group size varied significantly among the three main surveyed sub-areas (Kruskal Wallis, $\mathrm{H}_{2,196}=29.85, \mathrm{p}=0.0000$ ). Groups were larger in Laranjeiras bay and smaller in Canal do Superagui. The physical environment, risk of predation, seasonal distribution and abundance of prey are the main possible factors driving larger groups in inner and protected waters.
\end{abstract}

Keywords: Cetacea, Sotalia guianensis, group size, Guiana dolphin.

\section{Tamanho e composição de grupos do boto-cinza (Sotalia guianensis) (Van Bénèden, 1864) no Complexo Estuarino de Paranaguá, Brasil}

\begin{abstract}
Resumo
O objetivo do presente estudo foi descrever as características do tamanho e da composição de grupos do boto-cinza (S. guianensis) no Complexo Estuarino de Paranaguá (25 $15^{\circ}-25^{\circ} 36^{\prime} \mathrm{S}$ and $48^{\circ} 02^{\prime}-48^{\circ} 45^{\prime}$ O), Estado do Paraná, assim como de verificar a possível existência de relações entre uma dada variável ambiental (profundidade, salinidade, transparência e temperatura da água) e o tamanho de grupo. Uma área de aproximadamente $124 \mathrm{~km}^{2}$ foi investigada com uso de barco a motor entre abril de 2006 e fevereiro de 2008 nas seguintes sub-áreas do estuário: Canal do Superagui $\left(\sim 28 \mathrm{~km}^{2}\right)$, baía dos Pinheiros $\left(\sim 34 \mathrm{~km}^{2}\right)$, parte da baía das Laranjeiras que incluiu o sub-estuário de Guaraqueçaba $\left(\sim 38 \mathrm{~km}^{2}\right)$, e parte da Seção de Mistura do Complexo Estuarino de Paranaguá $\left(\sim 24 \mathrm{~km}^{2}\right)$. Em 45 dias de investigação, um total de 147 horas foi empregado na observação de 286 grupos de $S$. guianensis. Numericamente os grupos variaram entre dois e 90 indivíduos (média \pm DP: 11,5 \pm 14,4 indivíduos). Indivíduos solitários foram observados em apenas cinco ocasiões $(1,7 \%$ de todas as observações). Grupos com filhotes $(n=247)$ representaram $86,4 \%$ de todos os observados e foram mais comuns em todas as sub-áreas quando comparados com grupos sem filhotes. Grupos sem filhotes foram geralmente compostos por até 12 indivíduos e encontrados em todas as subáreas. Uma comum composição de grupo de cerca de $70 \%$ de adultos e $30 \%$ de filhotes foi observada considerando todas as sub-áreas e estações do ano. Não foram apontados correlações entre o tamanho de grupo e a temperatura
\end{abstract}


(Teste de Rank de Spearman, $r=0,0059 ; \mathrm{p}=0,9338$ ), a transparência (Teste de Rank de Spearman, $r=0,0597$; $\mathrm{p}=0,9333$ ), a profundidade (Teste de Rank de Spearman, $\mathrm{r}=0,1421 ; \mathrm{p}=0,4698$ ), e a salinidade da água (Teste de Rank de Spearman, $r=-0,1938 ; p=0,0665)$. Enquanto grupos de botos-cinza foram observados ao largo de todo o estuário, seus tamanhos variaram significativamente entre a três sub-áreas principais (Kruskal Wallis, $\mathrm{H}_{2,196}=29,85$; $\mathrm{p}=0,0000$ ). Grupos foram maiores na baía das Laranjeiras e menores no Canal do Superagui. A topografia, o risco de predação, a distribuição sazonal e a abundância de presas são apontadas como os principais fatores que favoreceram a formação de maiores tamanhos de grupos em águas mais internas e protegidas.

Palavras-chave: Cetacea, Sotalia guianensis, tamanho de grupo, Boto-cinza.

\section{Introduction}

Group size in small cetaceans can be dictated by many factors such as predation risk, abundance and distribution of prey, physical environment, reproduction, and cetacean abundance (Connor, 2000; Heithaus, 2001; Gygax, 2002). It is known that small-sized dolphins in open waters seem to be more vulnerable to predators and tend to form larger aggregations for their own protection, as well as to find patchy food resources in a vast area (Norris and Dohl, 1980; Wells et al., 1987; Gygax, 2002). On the other hand, there is a tendency to find smaller aggregations of dolphins in inner protected waters (Würsig, 1986; Gygax, 2002). Small cetaceans organised in fission-fusion societies tend to select their habitat and group size based on ecological conditions and their current activity, which includes reproductive and foraging purposes (Heithaus, 2001). As a consequence, in order to understand the dynamics about the use of the area of dolphin populations, it is important to gather information on the characteristics of their associations, as well as on the habitat in which they are found.

Along the Brazilian coast, Guiana dolphins Sotalia guianensis (Van Bénèden, 1864) represent the main target for cetacean ecological studies in their habitat. This species can only be found in coastal and estuarine waters of the Western South Atlantic, from southern Brazil to Honduras (Flores, 2002). In the last 15 years, when several populations have been surveyed through photoidentification, the knowledge on the species ecology has been considerably upgraded (see Flores, 1999; Santos et al., 2001; Azevedo et al., 2004; Flores and Bazallo, 2004; Azevedo et al., 2005; Flores and Fontoura, 2006; Azevedo et al., 2007; Santos and Rosso, 2007; 2008). However, even after the quoted progress, the biology and the conservation status of $S$. guianensis remain poorly understood. As a result, the species is still listed as "data deficient" by the World Conservation Union (Reeves et al., 2003; IUCN, 2006).

One of the best-known populations of S. guianensis dwells in the northern range of the Lagamar estuary $\left(\sim 24-25^{\circ} \mathrm{S}\right)$, southeastern Brazil. The latter includes inshore waters from Iguape ( $24^{\circ} 36^{\prime} \mathrm{S}$ and $\left.47^{\circ} 23^{\prime} \mathrm{W}\right)$, São Paulo State, to Pontal do Sul (25 $36^{\circ} \mathrm{S}$ and $48^{\circ} 25^{\prime} \mathrm{W}$ ), Paraná State. Large mangrove forests and salt marshes surround the whole estuary, which is characterised by muddy bottom, shallow (up to $27 \mathrm{~m}$ ) and relatively turbid waters with high concentrations of nutrients, zooplankton, shrimp, and fish found year-round (Besnard, 1950; Sinque et al., 1982; Brandini, 1985; Corrêa, 1987; Knoppers et al., 1987; Schaeffer-Novelli et al., 1990; Mendonça and Katsuragawa, 1997; Corrêa, 2000). Due to their ecological importance, several areas of the Lagamar estuary were designated as protected reserves in the 1980s (see Schaeffer-Novelli et al., 1990; IPARDES, 2001), and further studies on ecology are still necessary to reinforce the needs for nature conservation.

In its northern range, specifically around the Cananéia island $\left(25^{\circ} 00^{\prime} \mathrm{S}\right.$ and $\left.47^{\circ} 50^{\prime} \mathrm{W}\right)$ and adjacent areas, S. guianensis has been the focus of several studies since the1990s, including behaviour (Santos et al., 2000), feeding habits (Santos et al., 2002), age estimation (Santos et al., 2003), contaminant loads (Yogui et al., 2003), acoustics (Pivari and Rosso, 2005), group size and composition (Santos and Rosso, 2007), and social organization (Santos and Rosso, 2008). In a threeyear survey in the mentioned estuary, Santos and Rosso (2007) showed that $S$. guianensis group size ranged from 2 to 60 individuals (mean $\pm \mathrm{SD}=12.4 \pm 11.4$ individuals). Associations among Guiana dolphins were fluid, showing strong evidence of a fission-fusion social organisation (Santos and Rosso, 2008). S. guianensis is also found in the southern range of the Lagamar estuary, more precisely in the Paranaguá Estuarine Complex $\left(\sim 25^{\circ} 24^{\prime} \mathrm{S}\right.$ and $\left.48^{\circ} 24^{\prime} \mathrm{W}\right)$ sensu Noernberg et al. (2006). The quoted area is inserted in the northeast portion of Paraná state, where S. guianensis can be found year round, but is still poorly known. A few studies were based on dead individuals found after the recovery along the coast (e.g. Rosas and Monteiro-Filho, 2002; Rosas et al., 2003). So far, there have been no published studies based on the observation of live individuals in their habitat. Thus, there is a lack of knowledge to be fulfilled regarding population parameters of a top predator in a highly productive ecosystem.

Based on the described scenario, the aim of the present study was to describe the characteristics of $S$. guianensis group size and composition in the Paranaguá Estuarine Complex, as well as to verify the existence of relationships between group size and a given environmental 
variable (water depth, salinity, transparency and temperature). These variables were chosen because they have a significant influence on lower trophic level species abundance and distribution in tropical and subtropical estuarine ecosystems, mainly when considering rainy and dry seasons (Day-Jr. et al., 1989). As a consequence, top predators adapt the way they use the area through time and space. These factors might influence group formation in S. guianensis in different subsets of the estuary, as well as in coastal waters. Understanding how environmental factors may affect living organisms is relevant to describe the dynamics of the ecosystem and, therefore, to achieve conservation purposes.

\section{Materials and Methods}

\subsection{Study area}

The Paranaguá Estuarine Complex, here called PEC $\left(25^{\circ} 15^{\prime} \mathrm{S}-25^{\circ} 36^{\prime} \mathrm{S}\right.$ and $\left.48^{\circ} 02^{\prime} \mathrm{W}-48^{\circ} 45^{\prime} \mathrm{W}\right)$, is a large interconnected subtropical estuarine system comprising two main water bodies (Lana et al., 2000) (Figure 1). It has $3.870 \mathrm{~km}^{2}$ of watershed area, from which $551.8 \mathrm{~km}^{2}$ represents the main water body (Noernberg et al., 2006). This estuarine complex is composed of five smaller sections including the main bays: Antonina, Paranaguá, Laranjeiras, Pinheiros, and a Mixture Section. According to Noernberg et al. (2006), Laranjeiras bay is composed of four sub-estuaries, called: Medeiros, Itaqui, Benito and Guaraqueçaba.

The present study was conducted in Pinheiros bay, as well as in a section of Laranjeiras bay, including the whole sub-estuary of Guaraqueçaba, and in part of the Mixture Section including the area between Ilha das Peças and Ilha do Mel (Figure 1). In Pinheiros bay, the decision was to split the area in two, in order to address the investigation of groups in a whole day in both subsets. One of the surveyed areas was named Canal do Superagui and the other Pinheiros bay. The $14 \mathrm{~km}$ long channel connecting the main body of water from Pinheiros bay to coastal waters represents Canal do Superagui. The remaining area represents Pinheiros bay. Therefore, a total area of around $124 \mathrm{~km}^{2}$ of the PEC was surveyed in the following sub-areas: Canal do Superagui

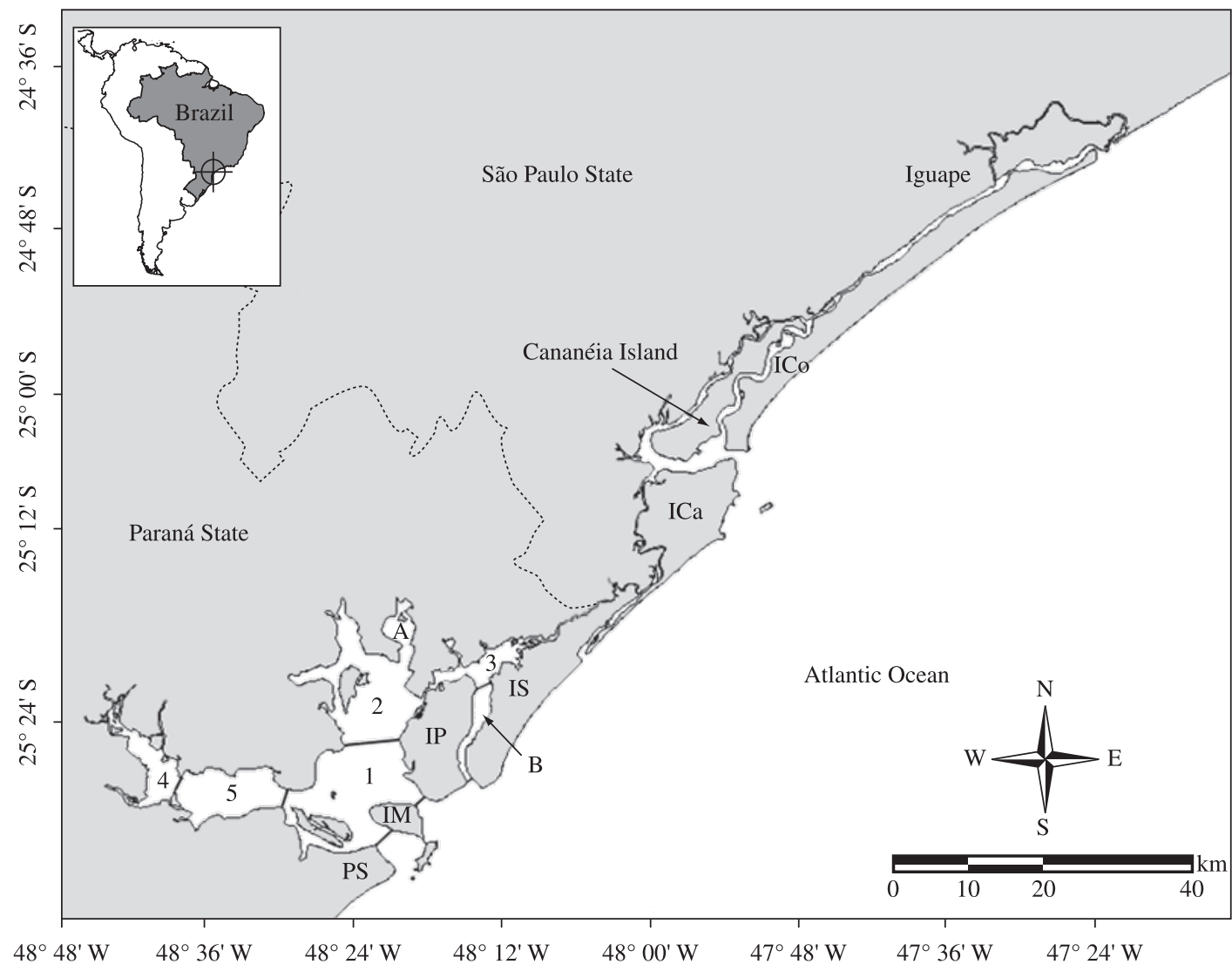

Figure 1. The Lagamar estuary, from Iguape, São Paulo State, to Pontal do Sul (PS), Paraná State, showing the surveyed area where Guiana dolphins (Sotalia guianensis) were studied in the Paranaguá Estuarine Complex $\left(25^{\circ} 15^{\prime}-25^{\circ} 36^{\prime} \mathrm{S}\right.$ and $\left.48^{\circ} 02^{\prime}-48^{\circ} 45^{\prime} \mathrm{W}\right)$. Sectors 1 = Mixture Section; 2 = Laranjeiras; 3 = Pinheiros; 4 = Antonina; 5 = Paranaguá. Sub-estuaries A = Guaraqueçaba; B = Canal do Superagui. IM = Ilha do Mel; IP = Ilha das Peças; IS = Ilha do Superagui; ICa = Ilha do Cardoso; ICo = Ilha Comprida; PS = Pontal do Sul. Modified from Noernberg et al. (2006). 
(denominated "Canal" in the present study) $\left(\sim 28 \mathrm{~km}^{2}\right)$, "Pinheiros" bay $\left(\sim 34 \mathrm{~km}^{2}\right)$, part of Laranjeiras bay, which included the Guaraqueçaba sub-estuary and is called "Laranjeiras" in this study $\left(\sim 38 \mathrm{~km}^{2}\right)$, and part of the Mixture Section close to Ilha das Peças called "Peças" in this study $\left(\sim 24 \mathrm{~km}^{2}\right)$ (see Figure 1). There are no biological and/or physical barriers isolating these four sub-areas. They were stratified in order to cover a significant part of the area where dolphins can be found in a lesser amount of days. Two sub-areas were usually surveyed in a given day.

\subsection{Data collection}

Fieldwork was conducted as part of a long-term investigation on the ecology of $S$. guianensis in the Lagamar estuary. Basically, fieldwork has been conducted through boat-based observations using the photo-identification technique to monitor individually recognizable dolphins through time and space (Würsig and Würsig, 1977). Boat-based (15 hp motorised vessels) surveys were conducted from April 2006 to February 2008 in six different seasons: autumn, winter and spring of 2006, summer and winter of 2007, and summer of 2008. Seasons were divided as follows: summer (December-February), autumn (March-May), winter (June-August), and spring (September-November). All sub-areas but the Mixture Section were surveyed in all seasons. The latter was included in surveys mainly from the summer of 2008 on. Survey days lasted from 8 to 12 days in each season, covering each subset of the estuary at least four times. The survey path followed a random zig-zag pattern in order to maximise the chances of encountering dolphins. Surveys were only conducted in good sea conditions (Beaufort Scale $\leq 2$ ). When a group of dolphins was found, the boat approached it for the photo-identification study and to gather the information on group size and composition. A group of Guiana dolphins was defined as any aggregation of two or more individuals, including female-calf pairs, observed in close proximity to each other within a radius of approximately $50 \mathrm{~m}$ (Santos and Rosso, 2007). These aggregations were generally, but not necessarily, engaged in similar activities. Although rarely seen, lone dolphins were also counted and included in the analyses. Groups with more than 20 individuals had their numbers estimated. Two distinct types of groups were defined: (1) with and (2) without calves. Calves were characterised to be $1 / 2$ or less in size than the largest individuals in the group. When calves were observed, the number of newborns was noted. Newborns were easily distinguished within a group by their fetal folds, which can be seen along the sides of their bodies, as well as the slapping of their heads on the surface of the water when breathing. Data on environmental characteristics were collected when groups were found: water salinity (handheld refractometer), transparency (Secchi disk), depth (echo-sounder; every five minutes), and temperature at the surface (alcohol thermometer)

\subsection{Data analysis}

Environmental data were plotted for comparisons among seasons, as well as sub-areas. Emphasis was given to summer and winter seasons, as both seasons were surveyed twice. The null hypothesis that there were no differences among the following parameters was tested: (1) water depth among sub-areas, (2) water temperature at surface between seasons, (3) water salinity between seasons in the same sub-area and (4) among sub-areas in the same season, (5) water transparency between seasons in the same sub-area and (6) among sub-areas in the same season. Group sizes were divided into the following categories: 1 to 5,6 to 10,11 to 15,16 to 20 , and $21+$ individuals. Data were plotted for comparisons among sub-areas. The null hypotheses that (7) there were no differences in group size when comparing the surveyed subareas, as well as in (8) seasonal variation of group size in the same subset of the surveyed estuarine complex, were also tested. Spearman correlation analyses were performed in order (9) to evaluate the relationship between group size and each of the four environmental variables. According to the characteristics of the gathered data (see Siegel, 1975; Sokal and Rolf, 1995), for investigations (1) to (9) non-parametric analyses were performed using the software Statistica for Windows ${ }^{\circledR} 6.0$ (StatSoft, Inc., Tulsa, OK, USA). Non-parametric statistics were used to analyse the environmental data because distributions were not normal. The 5\% significance level was adopted for all tests.

\section{Results}

In 45 survey days in four sub-areas from April 2006 to February 2008, a total of 147 hours were spent observing 286 groups of $S$. guianensis in the following areas of the PEC: Laranjeiras (40.9\% of all efforts), Pinheiros (28.5\%), Canal (24.4\%), and Mixture Section (7.7\%). Groups varied from two individuals to aggregations of

Table 1. Group size and composition of Guiana dolphins (Sotalia guianensis) observed in four sub-areas of the Paranaguá Estuarine Complex from April 2006 to February 2008. SD = Standard Deviation, Nbs = Newborns.

\begin{tabular}{lcccccccc}
\hline \multicolumn{1}{c}{ Sub-areas } & \# Groups & Mean \pm SD & Median & Variation & \# Adults & \# Calves & \# Nbs & \% Nbs \\
\hline Canal & 87 & $5.3 \pm 3.6$ & 4.0 & 1 to 20 & 314 & 143 & 17 & 12 \\
Pinheiros & 81 & $12.7 \pm 17.1$ & 6.0 & 1 to 80 & 656 & 273 & 61 & 22 \\
Laranjeiras & 98 & $14.2 \pm 15.2$ & 8.5 & 2 to 90 & 902 & 409 & 37 & 9 \\
Mixture Section & 20 & $23.3 \pm 19.2$ & 15.0 & 5 to 80 & 213 & 104 & 10 & 10 \\
Overall & 286 & $11.5 \pm 14.4$ & 6.0 & 1 to 90 & 2085 & 929 & 125 & 13 \\
\hline
\end{tabular}

$\#=$ number of 
Table 2. Group size and composition of Guiana dolphins (Sotalia guianensis) observed in three sub-areas of the Paranaguá Estuarine Complex in winter and summer seasons from July 2006 to February 2008. SD = Standard Deviation, Nbs = Newborns.

\begin{tabular}{lccccccc}
\hline Sub-areas & \# Groups & Mean \pm SD & Variation & \# Adults & \# Calves & \# Nbs & \% Nbs \\
\hline Canal & 56 & $5.2 \pm 3.5$ & 1 to 20 & 205 & 87 & 9 & 10 \\
Pinheiros & 64 & $8.4 \pm 10.1$ & 1 to 60 & 378 & 160 & 12 & 8 \\
Laranjeiras & 76 & $15.4 \pm 16.2$ & 2 to 90 & 805 & 365 & 42 & 12 \\
Overall & 196 & $11.5 \pm 14.4$ & 1 to 90 & 1388 & 612 & 63 & 10 \\
\hline
\end{tabular}

\# = number of

Table 3. Group size and composition of Guiana dolphins (Sotalia guianensis) observed in three sub-areas of the Paranaguá Estuarine Complex in winter and summer seasons from July 2006 to February 2008, with details on mean and standard deviation $(\mathrm{SD})$ values gathered on water salinity (ppm), transparency $(\mathrm{m})$, and temperature $\left({ }^{\circ} \mathrm{C}\right)$.

\begin{tabular}{llccccc}
\hline Sub-areas & Seasons & \# Groups & $\begin{array}{c}\text { Group Size } \\
\text { Mean } \pm \text { SD }\end{array}$ & $\begin{array}{c}\text { Salinity } \\
\text { Mean } \pm \text { SD }\end{array}$ & $\begin{array}{c}\text { Transparency } \\
\text { Mean } \pm \text { SD }\end{array}$ & $\begin{array}{c}\text { Temperature } \\
\text { Mean } \pm \text { SD }\end{array}$ \\
\hline Canal & Summer & 27 & $4.3 \pm 3.7$ & $25.4 \pm 3.8$ & $1.2 \pm 0.3$ & $27.6 \pm 0.9$ \\
& Winter & 29 & $6.1 \pm 3.2$ & $31.1 \pm 1.8$ & $2.4 \pm 0.8$ & $17.0 \pm 1.0$ \\
& Overall & 56 & $5.2 \pm 3.5$ & $28.4 \pm 4.1$ & $1.8 \pm 0.9$ & $22.1 \pm 5.4$ \\
Pinheiros & Summer & 34 & $9.8 \pm 11.9$ & $20.6 \pm 5.5$ & $1.1 \pm 0.2$ & $27.1 \pm 1.0$ \\
& Winter & 30 & $6.8 \pm 7.4$ & $28.6 \pm 1.9$ & $2.2 \pm 0.8$ & $17.4 \pm 0.9$ \\
& Overall & 64 & $8.4 \pm 10.1$ & $24.4 \pm 5.8$ & $1.6 \pm 0.8$ & $22.5 \pm 4.9$ \\
Laranjeiras & Summer & 40 & $14.0 \pm 12.0$ & $14.2 \pm 4.7$ & $1.0 \pm 0.6$ & $27.4 \pm 1.5$ \\
& Winter & 36 & $16.9 \pm 19.7$ & $24.2 \pm 3.3$ & $1.4 \pm 0.3$ & $16.9 \pm 1.2$ \\
& Overall & 76 & $15.4 \pm 16.2$ & $18.9 \pm 6.5$ & $1.2 \pm 0.5$ & $22.4 \pm 5.4$ \\
\hline
\end{tabular}

\# = number of

up to 90 individuals (Table 1). Solitary individuals were seen only in five occasions (1.7\% of all observations). Groups with calves $(n=247)$ represented $86.4 \%$ overall and were more common in all sub-areas when compared to groups without calves. Groups without calves were found in all sub-areas and were usually smaller and composed of up to 12 individuals. A usual group composition of $70 \%$ of adults and $30 \%$ of calves was observed considering all sub-areas and seasons. The largest number of newborns was observed in Pinheiros bay (Table 1). The gathered result was strongly influenced by the 2006 fall season, when newborns represented $35 \%$ from all observed calves, while in other seasons and sub-areas including Pinheiros bay, they ranged from 8 to $12 \%$ (Tables 1 and 2).

When considering the three main surveyed subareas in winter and summer seasons, 196 groups were reported $(68.5 \%$ overall) in 95 hours of direct observations (Table 2). In those three sub-areas, water depth ranged from 0.4 to $35.9 \mathrm{~m}$, with deeper waters found in Canal do Superagui (mean \pm SD: $14.1 \pm 7.9 \mathrm{~m} ; \mathrm{n}=249$ ) when compared to Pinheiros (mean \pm SD: $6.4 \pm 3.4 \mathrm{~m}$; $\mathrm{n}=337$ ) and Laranjeiras bay (mean $\pm \mathrm{SD}: 5.7 \pm 3.1 \mathrm{~m}$; $\mathrm{n}=337$ ) (Kruskal Wallis, $\mathrm{H}_{2,923}=229.02 ; \mathrm{p}=0.0000$ ). The water temperature varied from 15 to $31{ }^{\circ} \mathrm{C}$, with an expected significant difference observed when comparing summer and winter after joining data from the three sub-areas (Mann Whitney, $\mathrm{U}=12.09 ; \mathrm{p}=0.0000$ )
(Table 3). Differences were reported when comparing salinity values among sub-areas joining both seasons (Kruskal Wallis, $\mathrm{H}_{2,196}=39.52, \mathrm{p}=0.0000$ ). To address a more detailed investigation, Mann Whitney tests were performed to compare salinity values between seasons in each of the surveyed sub-areas with the following results: Canal, $\mathrm{U}=87.50, \mathrm{p}=0.0000$; Pinheiros, $\mathrm{U}=117.50, \mathrm{p}=$ 0.0000 ; and Laranjeiras, $U=64.50, p=0.0000$. As a general result, lower salinity values were usually found in inner waters in summer (Table 3). The water transparency varied from 0.4 to $3.8 \mathrm{~m}$. Differences were reported when comparing transparency values among sub-areas joining both seasons (Kruskal Wallis, $\mathrm{H}_{2,196}=26.45$, $\mathrm{p}=0.0000$ ). To address a more detailed investigation, Mann Whitney tests were performed to compare transparency values between seasons in each of the surveyed sub-areas with the following results: Canal, $\mathrm{U}=$ 58.00, $\mathrm{p}=0.0000$; Pinheiros, $\mathrm{U}=54.50, \mathrm{p}=0.0000$; and Laranjeiras, $\mathrm{U}=260.00, \mathrm{p}=0.0000$. As a general result, the water was darker in inner waters in summer (Table 3).

While Guiana dolphin groups were seen in the entire surveyed area, group size varied significantly among sub-areas (Kruskal Wallis, $\mathrm{H}_{2,196}=29.85, \mathrm{p}=0.0000$ ). Groups were larger in Laranjeiras bay and smaller in Canal do Superagui (Tables 2 and 3). Aggregations composed of more than 20 individuals were only reported in Pinheiros and Laranjeiras bay (Figure 2). No signifi- 


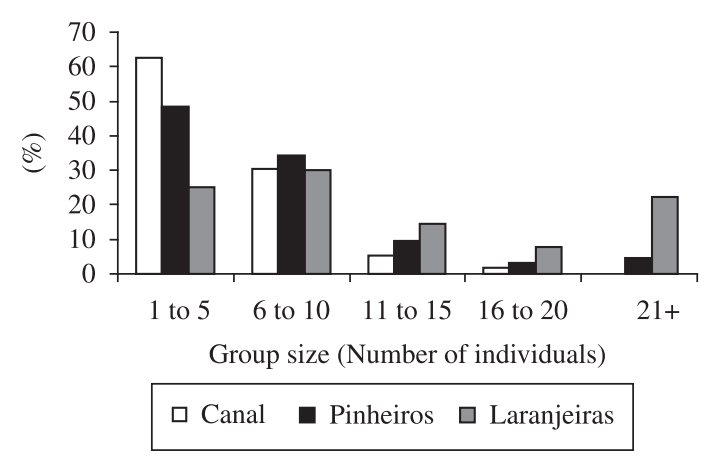

Figure 2. Frequency of Guiana dolphins group sizes found in the three surveyed sub-areas in the Paranaguá Estuarine Complex from July 2006 to February $2008(n=196)$. Group sizes were divided into the following categories: (1) 1 to 5 ; (2) 6 to 10 ; (3) 11 to 15 ; (4) 16 to 20 ; (5) 21+ individuals.

cant differences were observed when comparing group size between seasons for Laranjeiras (Mann Whitney, $\mathrm{U}=712.50, \mathrm{p}=0.9378$ ) and Pinheiros bay (Mann Whitney, $\mathrm{U}=338.50, \mathrm{p}=0.1210$ ). However, differences were detected when comparing group sizes between seasons in Canal do Superagui (Mann Whitney, U = 214.00, $\mathrm{p}=0.0036$ ), with quite larger groups observed in winter (Table 3).

No correlations were found between group size and water temperature (Spearman's rank test, $r=0.0059$, $\mathrm{p}=0.9338$ ), transparency (Spearman's rank test, $\mathrm{r}=0.0597, \mathrm{p}=0.9333$ ), depth (Spearman's rank test, $r=0.1421, p=0.4698)$, and salinity (Spearman's rank test, $r=-0.1938, p=0.0665)$.

\section{Discussion}

In order to investigate the characteristics of S. guianensis group size in the PEC, three main subareas were surveyed in this preliminary study. Because of a few limitations including available time and budget for fieldwork, it was not possible to survey the whole PEC. Laranjeiras, Pinheiros and Canal do Superagui were chosen based on four previous visits to the site conducted between 2000 and 2003. On those occasions, S. guianensis was abundant in all quoted sites. However, as the research team got used to the site after the first attempts to cover the chosen sub-areas, it was possible to expand the surveyed areas to other estuarine subsets such as the Mixture Section sensu Noernberg et al. (2006). Regarding the surveyed sites, the decision to split the Pinheiros sub-estuary sensu Noernberg et al. (2006) in two sub-areas was definitely relevant and should be considered in further local studies on ecology. Several environmental characteristics (e.g. water salinity, transparency, depth), as well as S. guianensis group size, were significantly different when comparing the two remaining sub-areas.
The mean group size of $S$. guianensis in the PEC was $11.5 \pm 14.4(\mathrm{SD})$ individuals $(\mathrm{n}=286)$, which showed a large range from lone individuals to estimated aggregations of up to 90 dolphins. These results are quite similar to the ones observed in the Cananéia estuary (mean $\pm \mathrm{SD}=12.4 \pm 11.4$ individuals; $\mathrm{n}=374$ ), where the range varied from one up to around 60 individuals (Santos and Rosso, 2007). Besides that, the proportion of adults and calves was almost the same when comparing both sites in the Lagamar estuary (see Santos and Rosso, 2007), as well as the rarity when finding lone individuals. However, different from what was observed in the Cananéia estuary, a peak of newborns (35\% of all observed calves) was observed in Pinheiros bay in the 2006 fall season. Unfortunately no other fall seasons were monitored and further investigations would be necessary to gather more samples for comparisons. It is known that there is a tendency to observe calves all year round with no seasonal peaks in the same area (Rosas and MonteiroFilho, 2002).

All the monitored environmental data in the present study followed the tendencies found in several previous studies conducted in the PEC (e.g. Sinque et al., 1982; Brandini, 1985; 1987; Knoppers et al., 1987; Corrêa, 2000; Nogueira de Queiroz et al., 2006; Schwarz Jr. et al., 2006). As expected, inner waters are usually more turbid and less salty when compared to the areas close to the shore (see Table 3 ). The rainy summer season has an important influence on the lower salinity values observed and is also responsible to carry organic matter from the huge chain of mountains and mangrove forests found in close proximity to the inner areas of the estuary.

When analysing the characteristics of group sizes in both sites of the Lagamar estuary, as well as considering data from the literature (see a review in Santos and Rosso, 2007), it was interesting to observe that a different scenario was found in the PEC: larger groups observed in inner protected waters, and smaller ones close to the connection with coastal waters. Several reasons may explain the gathered results in the present study. The physical environment is known to be one of the main factors affecting group size in cetaceans (Gygax, 2002). In the present study we observed larger $S$. guianensis groups in Laranjeiras and Pinheiros bays when compared to Canal do Superagui. The latter is deeper when compared to the two mentioned sub-areas. No correlation was found between group size and water depth as was observed in the Cananéia estuary by Santos and Rosso (2007). In Cananéia, larger groups were usually found in the main estuary entrance of $4 \mathrm{~km}$ wide and an average of $14 \mathrm{~m}$ deep. In the present study, although $S$. guianensis groups were smaller in the surveyed connection to coastal waters from Canal do Superagui, we usually found larger groups composed of more than 20 individuals $(n=9)$ when monitoring the other connection with coastal waters placed between Ilha das Peças and Ilha do Mel. In that location, the sub-area width ranges from 2.5 to $5 \mathrm{~km}$ and depth from 7.2 to $27.6 \mathrm{~m}$. When compared to the in- 
ner subsets of the Cananéia estuary and other protected areas, both Pinheiros (up to $5 \mathrm{~km}$ ) and Laranjeiras bays (up to $10 \mathrm{~km}$ ) are wider, which amplifies the carrying capacity for dolphins using the area. On the other hand, Canal do Superagui has a maximum width of $2 \mathrm{~km}$, but is usually $1 \mathrm{~km}$ wide. With these characteristics, there is a natural tendency of finding smaller groups in narrower subsets of the estuary. As a consequence, it would be possible that the topography of the sub-area could influence the usually seen smaller group sizes in Canal do Superagui. Further studies should be addressed in order to verify the seasonal difference in group size observed in Canal do Superagui.

The risk of predation may also play a role in determining the size of groups in mammals (Bertram, 1978; Connor, 2000; Heithaus, 2001). To date, there is no published information on $S$. guianensis predators. Potentially, sharks and killer whales, Orcinus orca (Linnaeus, 1758) may prey upon S. guianensis. However, to date no attacks have been reported, nor is there evidence of scars or mutilated photo-identified individuals. A killer whale was recently witnessed attacking and killing a franciscana dolphin, Pontoporia blainvillei (Gervais \& d'Orbigny, 1844) in closer coastal waters (Santos and Netto, 2005), and the only known record of the presence of an individual killer whale was recently reported for the Cananéia estuary (Santos and Rosso, 2007). Interactions between sharks (order Selachii) and dolphins (order Cetacea, suborder Odontoceti) have been reported worldwide (see Heithaus, 2001 for a review of shark predation on dolphins). Such interactions are usually reported from the investigation of stomach contents, from occasional opportunities witnessed in the field, and from observations on wounds and scars on living and dead scavenged individuals. Heithaus (2001) showed that the remains of at least 24 toothed whale species were already found in shark stomachs, but $S$. guianensis was not listed. On 16 February 2008, during one of the survey days in Canal do Superagui, an adult Guiana dolphin was photographed without its dorsal fin in a group

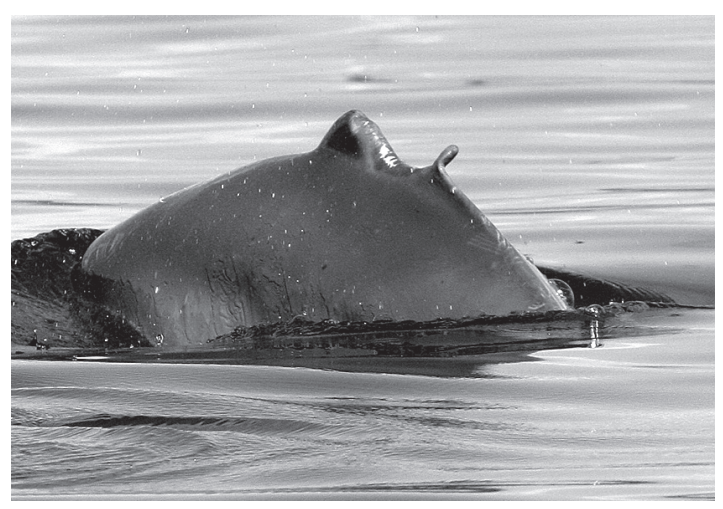

Figure 3. Left side of the body of an adult Guiana dolphin (Sotalia guianensis) showing a healed wound provoked by a shark predation attempt which took off the dorsal fin. of 20 individuals composed of 14 adults and 6 calves, all photographed. A detailed analysis of the photographs (see Figure 3) showed that the wound was certainly provoked by a shark bite, probably the result of a failed predation attempt. However, it was not possible to ascertain the species responsible for the unwitnessed attack, as well as to know if the attack occurred in inner or outer waters. The bull shark, Carcharhinus leucas (Müller \& Henle, 1839), commonly found in local coastal waters and already found in inner estuarine waters of Cananéia (Sadowsky, 1971), and listed as a regular predator of small cetaceans (Heithaus, 2001), may be listed as a potential candidate for the observed bite. An investigation on the feeding habits of several shark species found in local (inshore and offshore) waters may render more clues on their possible interactions with $S$. guianensis. According to Heithaus (2001), to understand group sizes and habitat use of dolphins, it is important to understand the relative risk to an individual odontocete from predators, particularly sharks, in different habitats.

Another reason listed in the literature driving group associations in mammals is the distribution and abundance of prey (Bertram, 1978; Norris and Dohl, 1980; Connor, 2000; Heithaus, 2001; Gygax, 2002). Several studies described the seasonal occurrence of fish in the PEC (e.g. Corrêa, 1987; 2000; Nogueira de Queiroz et al., 2006; Schwarz Jr. et al., 2006). In all studies, catfish species (Ariidae) were usually listed as the most common, followed by Stellifer rastrifer (Jordan, 1889) and $S$. brasiliensis (Schultz, 1945) (Sciaenidae). Corrêa (2000) described the presence of fish from the genus Stellifer all year round in local estuarine waters for growing, maturation, recruitment, and reproduction purposes. According to Corrêa (1987), fishes from the genus Stellifer are of no interest to local fishermen who usually discard this resource in fishing operations. The two mentioned species are bottom-dwelling fish (Menezes and Figueiredo, 1980) known to be the main prey items of $S$. guianensis in the Cananéia estuary (Santos et al., 2002; Santos and Rosso, 2007). They may also play an important role in the diet of Guiana dolphins in the surveyed area. In tropical and subtropical estuarine systems, Sciaenid fishes are usually dominant (Blaber, 2002) and, as an opportunistic feeder, S. guianensis takes advantage of such abundance. Feeding aggregations composed of more than 20 dolphins were usually observed in Pinheiros and Laranjeiras bay. Several individuals usually showed mud attached to their bodies when surfacing for breathing, which was already related to a bottomfeeding clue in other studies (Santos et al., 2002; Santos and Rosso, 2007). Zanelatto (2001) showed that teleost fishes represented $91.5 \%$ of the food items found in a sample of 35 stomach contents collected from Guiana dolphins found dead in the PEC. Sciaenid fishes represented $25.5 \%$ of all food items. The most common species found were the barbel stradrum, Ctenosciaena gracilicirrhus (Metzelaar, 1919) and the rake stardrum (Stellifer rastrifer). An interesting observation from 
that study came from the importance of Clupeid fishes in winter, mainly the coastal pellona, Pellona harroweri (Fowler, 1917). As was observed for the CE, Clupeid fishes are found in high abundance in protected estuarine waters for maturation in winter when they serve as nourishment for Guiana dolphins (Santos \& Rosso, 2007). Usually, schools are large and attract higher numbers of dolphins and other predators such as seabirds for a feast. This is an important factor that can lead to the formation of large groups of Guiana dolphins in winter.

As previously expected for a large estuarine area in a sub-tropical region, environmental data showed a high variability (see Table 3 ). It is known that water depth and salinity affects the seasonal composition, diversity, abundance and distribution of fish (Moyle and Cech Jr., 1988; Day-Jr., et al., 1989; Corrêa, 2000). In the surveyed estuarine system, Corrêa (2000) showed that higher abundances of $S$. rastrifer were usually associated with lower salinity and higher transparency values. In our analyses, larger groups of $S$. guianensis were found in inner protected areas, which usually present the same quoted characteristics. This pattern was not observed in the Cananéia estuary (see Santos and Rosso, 2007). Probably the use of larger and protected subsets of the estuary with plenty of available food items led to the observed group size patterns in the PEC.

Other population parameters of the surveyed population are under investigation, with emphasis on abundance based on capture-recapture models, as well as associations among individuals, both after photo-identification efforts. With these additional pieces of the puzzle, more details will be available to better understand the way $S$. guianensis forms groups in the PEC. Joining the gathered results and further observations it would be possible to answer questions like: if a large school of Clupeid fishes is found in Canal do Superagui in winter, would Guiana dolphins aggregate in larger numbers for feeding bouts? Further information on feeding habits based on the analyses of stomach contents would also render an important pathway to describe $S$. guianensis associations in a huge and complex estuary. As an important element of the trophic level in a highly productive ecosystem, the knowledge on a flagship species like S. guianensis will represent an important tool for the PEC conservation purposes. Recent observations on skin diseases affecting Guiana dolphins showed evidence that the mentioned ecosystem is likely to be compromised by pollution (see Van Bressem et al., 2009).

Ackowledgements - Fundação de Amparo à Pesquisa do Estado de São Paulo (FAPESP) provided grants Programa Jovem Pesquisador em Centros Emergentes. The Earthwatch Institute sponsored the equipment used in the field. Grants came from the Cetacean Society International and the Whale and Dolphin Conservation Society for photo-identification studies. JEFO and ESP received a two-year fellowship (20072008) from Programa de Recursos Humanos da ANP para o Setor Petróleo e Gás - PRH-ANP/MCT, Convênio UNESPMCT-ANP. Support in the field was provided by the Instituto Oceanográfico da Universidade de São Paulo, as well as the
Núcleo Pro-Ação, Guaraqueçaba - Pontifícia Universidade Católica do Paraná. Dr. Michael Heithaus and Dr. Otto Gadig analysed the photographs showing the shark bite on a Guiana dolphin. One anonymous referee made useful suggestions to improve the manuscript.

\section{References}

AZEVEDO, AF., LAÍlSON-BRITO, J., CUNHA, HA. and VAN SLUYS, M., 2004. A note on site fidelity of marine tucuxis (Sotalia fluviatilis) in Guanabara bay, southeastern Brazil. Journal of Cetacean Research and Management, vol. 6, no. 3 , p. $265-268$.

AZEVEDO, AF., VIANA, SC., OLIVEIRA, AM. and VAN SLUYS, M., 2005. Group characteristics of marine tucuxis (Sotalia fluviatilis) in Guanabara bay, south-eastern Brazil. Journal of the Marine Biological Association, U.K., vol. 85, no. 1 , p. 209-212.

AZEVEDO, AF., OLIVEIRA, AM., VIANA, SC. and VAN SLUYS, M., 2007. Habitat use by marine tucuxi dolphins (Sotalia guianensis) (Cetacea: Delphinidae) in Guanabara Bay, south-eastern Brazil. Journal of the Marine Biological Association, U.K., vol. 87, no. 1, p. 201-205.

BERTRAM, BCR., 1978. Living in groups: predators and prey. In KREBS, JR. and DAVIES, NB. (Eds.). Behavioural Ecology: an evolutionary approach. Oxford: Blackwell. p. 64-96.

BESNARD, W., 1950. Considerações gerais em torno da região lagunar de Cananéia-Iguape I. Boletim do Instituto Paulista de Oceanografia, São Paulo, vol. 1, no. 1, p. 9-26.

BLABER, SJM., 2002. Fish in hot water: the challenges facing fish and fisheries research in tropical estuaries. Journal of Fish Biology, vol. 61, Suppl. A, p. 1-20.

BRANDINI, FP., 1985. Ecological studies in the Bay of Paranaguá. I- Horizontal distribution and seasonal dynamics of the phytoplancton. Boletim do Instituto Oceanográfico (São Paulo), vol. 33, no. 2, p. 139-147.

CONNOR, RC., 2000. Group living in whales and dolphins. In MANN, J., CONNOR, RC., TYACK, PL. and WHITEHEAD, H. (Eds.). Cetacean Societies: field studies of dolphins and whales. Chicago: University of Chicago Press. p. 199-218.

CORRÊA, MFM., 1987. Ictiofauna da Baía de Paranaguá e Adjacências (litoral do Estado do Paraná - Brasil). Levantamento e Produtividade. Curitiba, PR: Universidade Federal do Paraná - UFPR. 396 p. [Masters Dissertation]

CORRÊA, MFM., 2000. Ictiofauna demersal da Baía de Guaraqueçaba (Paraná, Brasil). Composição, estrutura, distribuição espacial, variabilidade temporal e importância como recurso. Curitiba, PR: Universidade Federal do Paraná UFPR. 160 p. [Doctoral Thesis]

DAY-JR, JW., HALL, CAS., KEMP, WM. and YANEZARANCIBIA, A., 1989. Estuarine Ecology. New York: John Wiley and Sons.

FLORES, PAC., 1999. Preliminary results of a photoidentification study of the marine tucuxi Sotalia fluviatilis in southern Brazil. Marine Mammal Science, vol. 15, no. 3, p. 840-847.

2002. Tucuxi Sotalia fluviatilis. In PERRIN, WF., WÜRSIG, B. and THEWISSEN, JGM. (Eds.). Encyclopedia of Marine Mammals. San Diego, CA: Academic Press. p. 1267-1269. 
FLORES, PAC. and BAZALLO, M., 2004. Home ranges and movement patterns of the marine tucuxi dolphin, Sotalia fluviatilis, in Baía Norte, Southern Brazil. Latin American Journal of Aquatic Mammals, vol. 3, no. 1, p. 37-52.

FLORES, PAC. and FONTOURA, N., 2006. Ecology of marine tucuxi, Sotalia guianensis, and bottlenose dolphin, Tursiops truncatus, in Baía Norte, Santa Catarina state, southern Brazil. Latin American Journal of Aquatic Mammals, vol. 5, no. 2, p. $105-115$

GYGAX, L., 2002. Evolution of group size in the dolphins and porpoises: interspecific consistency of intraspecific patterns. Behavioral Ecology, vol. 13, no. 5, p. 583-590.

HEITHAUS, MR., 2001. Predator-prey and competitive interactions between sharks (order Selachii) and dolphins (suborder Odontoceti): a review. Journal of Zoology, (London), vol. 253, no. 1, p. 53-68.

INSTITUTO PARANAENSE DE DESENVOLVIMENTO ECONÔMICO E SOCIAL - IPARDES., 1990. Macrozoneamento da Área de Proteção Ambiental de Guaraqueçaba. vol. 1. Curitiba, PR. 254p.

INTERNATIONAL UNION FOR NATURE CONSERVATION - IUCN., 2006. Sotalia guianensis. In IUCN. 2006 IUCN Red List of Threatened Species. [on-line]. Available from: <http:// www.iucnredlist.org.>. Access in: 23 abr. 2008.

KNOPPERS, BA., BRANDINI, FP. and THAMM, CA., 1987. Ecological studies in the bay of Paranaguá II - Some physical and chemical characteristics. Nerítica (Pontal do Sul), vol. 2, no. 1, p. 1-36.

LANA, PC., MARONE, E., LOPES, RM. and MACHADO, EC., 2000. The subtropical estuarine complex of Paranaguá Bay, Brazil. In SEELIGER, U., LACERDA, LD. and KJERFVE, B. (Eds.). Coastal Marine Ecosystems of Latin America. Berlim: Springer Verlag. p. 131-145.

MENDONÇA, JT. and KATSURAGAWA, M., 1997. Desembarque da pesca costeira em Cananéia, São Paulo, Brasil, durante 1995 e 1996. Nerítica, Pontal do Sul, vol. 11, p. $165-190$.

MENEZES, NA. and FIGUEIREDO, JL., 1980. Manual de Peixes Marinhos do Sudeste do Brasil IV: Teleostei (3). São Paulo: Museu de Zoologia, Universidade de São Paulo. 96 p.

MOYLE, PB. and Cech jr, JJ., 1988. Fishes: an introduction to ichthyology. New Jersey:Prentice Hall.

NOERNBERG, MA., LAUTERT, LFC., ARAÚJO, AD., MARONE, E., ANGELOTTI, JPB., NETTO JR. and KRUG, LA., 2006. Remote sensing and GIS integration for modelling the Paranaguá estuarine complex - Brazil. Journal of Coastal Research, Special Issue 39, p. 1627-1631.

NOGUEIRA DE QUEIROZ, GM., SPACH, HL., SOBOLEWSKI-MORELOS, M., SANTOS, L. de O. and SCHWARZ Jr, R., 2006. Caracterização da ictiofauna demersal de duas áreas do complexo estuarino de Paranaguá, Paraná, Brasil. Biociências, Porto Alegre, vol. 14, no. 2, p. 112-124.

NORRIS, KS. and DOHL, TP., 1980. The structure and functions of cetacean schools. In HERMAN, LM. (Ed.). Cetacean Behavior: mechanisms and functions. New York, NY: John Wiley and Sons. p. 211-261.
PIVARI, D. and ROSSO, S., 2005. Whistles of small groups of Sotalia fluviatilis during foraging behavior in southeastern Brazil. Journal of the Acoustic Society of America, vol. 118, no. 4 , p. $2725-2731$.

REEVES, RR., SMITH, BD., CRESPO, EA. and DI SCIARA, GN. (Eds.)., 2003. Dolphins, Whales and Porpoises: 20022010 conservation action plan for the world's cetaceans. Gland, Switzerland: IUCN - The World Conservation Union.

ROSAS, FCW. and MONTEIRO-FILHO, ELA., 2002. Reproduction of the estuarine dolphin (Sotalia guianensis) on the coast of Paraná, Southern Brazil. Journal of Mammalogy, vol. 83 , no. 2, p. 507-515.

ROSAS, FCW., BARRETO, AS. and MONTEIRO-FILHO, ELA., 2003. Age and growth of the estuarine dolphin (Sotalia guianensis) (Cetacea, Delphinidae) on the Paraná coast, southern Brazil. Fishery Bulletin, vol. 101, no. 2, p. 377-383.

SADOWSKY, V., 1971. Notes on the bull shark Carcharhinus leucas in the lagoon region of Cananéia, Brazil. Boletim do Instituto Oceanográfico, São Paulo, vol. 20, no. 2, p. 71-78.

SANTOS, MC. de O. and NETTO, DF., 2005. Killer whale (Orcinus orca) predation on a franciscana dolphin (Pontoporia blainvillei) in Brazilian waters. Latin American Journal of Aquatic Mammals, vol. 4, no. 1, p. 69-72.

SANTOS, MC. de O. and ROSSO, S., 2007. Ecological aspects of marine tucuxi dolphins (Sotalia guianensis) based on group size and composition in the Cananéia estuary, southeastern Brazil. Latin American Journal of Aquatic Mammals, vol. 6, no. 1, p. $71-82$

SANTOS, MC. de O. and ROSSO, S., 2008. Social organization of marine tucuxi dolphins, Sotalia guianensis, in the Cananéia estuary of southeastern Brazil. Journal of Mammalogy, vol. 88, no. 2, p. 347-355. de

SANTOS, MC. de O., ROSSO, S., SICILIANO, S., ZERBINI, A., ZAMPIROLLI, E., VICENTE, AF. and ALVARENGA, F., 2000. Behavioral observations of the marine tucuxi dolphin (Sotalia fluviatilis) in São Paulo estuarine waters, Southeastern Brazil. Aquatic Mammals, vol. 26, no. 3, p. 260-267.

SANTOS, MC. de O., ACUÑA, LB. and ROSSO, S., 2001. Insights on site fidelity and calving intervals of the marine tucuxi dolphin (Sotalia fluviatilis) in south-eastern Brazil. Journal of the Marine Biological Association, U.K., vol. 81, no. 6, p. 1049-1052.

SANTOS, MC. de O., ROSSO, S., SANTOS, RA., LUCATO, SHB. and BASSOI, M., 2002. Insights on small cetacean feeding habits in southeastern Brazil. Aquatic Mammals, vol. 28, no. 1, p. $38-45$.

SANTOS, MC. de O., ROSSO, S. and RAMOS, RMA., 2003. Age estimation of marine tucuxi dolphins (Sotalia fluviatilis) in south-eastern Brazil. Journal of the Marine Biological Association, U.K., vol. 83, no. 1, p. 233-236.

SCHAEFFER-NOVELLI, Y., MESQUITA, HSL. and CINTRÓN-MOLERO, G., 1990. The Cananéia lagoon estuarine system, São Paulo, Brazil. Estuaries, vol. 13, no. 2, p. 193-203.

SCHWARZ JR, R., FRANCO, ACNP., SPACH, HL., SARPEDONTI, V., PICHLER, HA. and NOGUEIRA de QUEIROZ, GML., 2006. Composição e estrutura da ictiofauna demersal na Baía dos Pinheiros, Paraná. Brazilian Journal of Aquatic Science and Technology, vol. 10, no. 1, p. 27-39. 
SIEGEL, S., 1975. Estatística Não-Paramétrica para as Ciências do Comportamento. São Paulo, SP, Brazil: Editora McGraw-Hill Ltda.

SINQUE, C., KOBLITZ, S. and COSTA, LM., 1982. Ictioplâncton do complexo estuarino Baía de Paranaguá e adjacencies $\left(25^{\circ} 10^{\prime}-25^{\circ} 35^{\prime} \mathrm{S}\right.$ e $\left.48^{\circ} 10^{\prime}-48^{\circ} 45^{\prime} \mathrm{W}\right)$, Paraná - Brasil - I. Aspectos gerais. Arquivos de Biologia e Tecnologia, vol. 25 , no. $3 / 4$, p. $279-299$.

SOKAL, RR. and ROLF, FJ. (Eds.)., 1995. Biometry: the principles and practice of statistics in biological research. $3^{\text {rd }}$ ed. New York, NY: W.H. Freeman and Company.

WELLS, RS., SCOTT, MD., and IRVINE, AB., 1987. The social structure of free-ranging bottlenose dolphins. In GENOWAYS, HH. (Ed.). Current Mammalogy. NY, United States: New York Plenium. p. 247-305.

WÜRSIG, B., 1986. Delphinid foraging strategies. In SCHUSTERMAN, RJ., THOMAS, JA. and WOOD, FG. (Eds.). Dolphin Cognition and Behavior: a comparative approach. Hillsdale, NJ: Lawrence Erlbaum Associates. p. 347-359.
WÜRSIG , B. and WÜRSIG, M. 1977. The photographic determination of group size, composition, and stability of coastal porpoises (T Tursiops truncatus). Science, vol. 198, no. 4318 , p. $755-756$.

YOGUI, GT., SANTOS, MC. de O. and MONTONE, RC., 2003. Chlorinated pesticides and polychlorinated biphenyls in marine tucuxi dolphins (Sotalia fluviatilis) from the Cananéia estuary, southeastern Brazil. Science of the Total Environment, vol. 312, no. 1-3, p. 67-78.

VAN BRESSEM, MF., SANTOS, MC de O. and OSHIMA, JEF., 2009. Skin diseases in Guiana dolphins (Sotalia guianensis) from the Paranaguá estuary, Brazil: a possible indicator of a compromised marine environment. Marine Environmental Research, vol. 67, no. 1, p. 63-68.

ZANELATTO, RC., 2001. Dieta do boto-cinza, Sotalia fluviatilis (CETACEA, DELPHINIDAE), no complexo estuarino da baía de Paranaguá e sua relação com a ictiofauna estuarina. Curitiba, PR: Universidade Federal do Paraná. 84 p. [Masters Dissertation] 